\title{
Confronting a Pandemic in Early Stages: A Retrospective Analysis From a Pandemic Hospital
}

\section{Pandeminin Erken Dönemiyle Yüzleşme: Bir Pandemi Hastanesinden Geriye Dönük Analiz}

\author{
๑ Ayşin Kılınç Toker ${ }^{1}$, ๑ Ayşegul Ulu Kılıç², ๑ Esma Eren ${ }^{1}$, ๑ Zehra Beştepe Dursun ${ }^{1}$, \\ ๑ İbrahim Toker $^{3}, \oplus$ Esma Saatçi ${ }^{4}, \oplus$ Illhami Çelik ${ }^{1}$ \\ ${ }^{1}$ Kayseri City Hospital, Clinic of Infectious Diseases and Clinical Microbiology, Kayseri, Turkey \\ ${ }^{2}$ Erciyes University Faculty of Medicine, Department of Infectious Diseases and Clinical Microbiology, Kayseri, Turkey \\ ${ }^{3}$ Kayseri City Hospital, Clinic of Emergency Medicine, Kayseri, Turkey \\ ${ }^{4}$ Kayseri City Hospital, Clinic of Medical Microbiology, Kayseri, Turkey
}

Background: Coronavirus disease-2019 (COVID-19) was spread worldwide by severe acute respiratory syndrome coronavirus-2. We aimed to examine demographic and clinical findings and prognosis of the patients during the first forty days of the pandemic in our country (March 13-April 23, 2020).

Materials and Methods: We analyzed the data of 561 COVID-19 patients hospitalized in a training and research hospital with a 1.607 bed capacity and 253 intensive care beds. Clinical, laboratory characteristics and radiographic findings were recorded and compared between intensive care unit (ICU) and non-ICU groups, and death and survived groups. Binary logistic regression analysis was used to identify independent risk factors for ICU admission and mortality.

Results: The patients' mean age was $53.5 \pm 20.3$ years, and the median age was 54 years (IQRs: $38-70) .53 .7 \%$ ( $n=301)$ of the patients were male. The average time between the onset of symptoms and admission to the hospital was 3.88 (standard deviation \pm 3.1 ) days. The median hospital stay of the patients was eight days (IQRs: 5-11). The most common symptoms in patients were fever [257 (45.8\%)], cough [333 (59.4\%)], shortness of breath [220 (39.2\%)], weakness [148 (26.4\%)], and myalgia [130 (23.2\%)]. While $21 \%$ of the patients $(n=118)$ had at least one comorbid disease, $21.7 \%(n=122)$ had more than one additional disease. The most common comorbidities were hypertension, diabetes mellitus and chronic obstructive pulmonary disease, with the rates of $20 \%, 16.8 \%$, and $15.3 \%$, respectively.

Conclusion: Significant risk factors for ICU care and mortality were as follows: 1 . Advanced age, 2. Having coronary artery disease and malignancy, 3. Leukocyte count over ten thousand, 4. Presence of lymphopenia, 5. Elevation of urea and creatinine, C-reactive protein, procalcitonin, Lactate dehydrogenase, D-dimer and cTnl. In our study, the thorax computed tomography played a vital corrective role in patients whose first real-time reverse transcription-polymerase chain reaction test was negative. Also, CURB-65 and qSOFA scores were significantly different in terms of mortality.

Keywords: COVID-19, clinical features, risk factors, prognosis

Amaç: Şiddetli akut solunum sendromu koronavirüs-2 neden olduğu koronavirüs hastalığı-2019 (COVID-19), dünya çapında hızla yayıldı. Bu çalışmada, ülkemizde pandeminin ilk kırk günündeki (13 Mart-23 Nisan 2020) hastaların demografik ve klinik özelliklerinin ve prognozlarının incelenmesi amaçlandı.

Gereç ve Yöntemler: Çalışmamızda, 253 yoğun bakım yatağı olan 1,607 yatak kapasiteli bir eğitim ve araştırma hastanesinde, COVID-19 tanılı 561 hastanın verileri analiz edildi. Yoğun bakım ünitesinde (YBÜ) ve yoğun bakım dışı takip edilen gruplar ile ölen ve hayatta kalan gruplar arasındaki klinik, laboratuvar özellikler ve radyografik bulgular karşılaştırıldı. Íkili lojistik regresyon analizi, yoğun bakım ünitesinde takip ve mortalite için bağımsız risk faktörlerini tanımlamak amacıyla kullanıldı.

Address for Correspondence: Ayşin Kilınç Toker, Kayseri City Hospital, Clinic of Infectious Diseases and Clinical Microbiology, Kayseri, Turkey Phone: +90 5054794287 E-mail: dr.aysin@gmail.com ORCID ID: orcid.org/0000-0002-6775-1234

Received: 05.12.2020 Accepted: 03.02.2021 
Bulgular: Hastaların ortalama yaşı 53,5ะ20,3 ve ortanca yaş 54 idi (IQRs: 38-70). Hastaların \%53,7'si (n=301) erkekti. Semptomların başlaması ile hastaneye başvuru arasında geçen ortalama süre 3,88 (standart sapma: $\pm 3,1$ ) gündü. Hastaların ortanca hastanede kalış süresi sekiz gündü (IQRs: 5-11). Hastalarda en sık görülen semptomlar, ateş [257 (\%45,8)], öksürük [333 (\%59,4)], nefes darlığı [220 (\%39,2)], halsizlik (148 [\%26,4)] ve miyaljiydi [130 (\%23,2)]. Hastaların \%21’i (n=118) en az bir komorbid hastalığa sahipken \%21,7'sinde ( $n=122$ ) birden fazla ek hastalık vardı. En sık görülen komorbiditeler hipertansiyon, diabetes mellitus ve kronik obstrüktif akciğer hastalığıydı (sırasıyla \%20, \%16,8, \%15,3).

Sonuç: Yoğun bakım ünitesinde takip ve mortalite için önemli risk faktörleri şöyle idi: 1. İleri yaş, 2. Koroner arter hastalığı ve maligniteye sahip olmak, 3. On bin üzeri lökosit sayısı, 4. Lenfopeni varlığı, 5. Üre ve kreatinin, C-reaktif protein, prokalsitonin, laktat dehidrogenaz, D-dimer ve cTnl yüksekliği. Ayrıca çalışmamızda toraks bilgisayarlı tomografi, ilk gerçek zamanlı ters transkripsiyon polimeraz zincir reaksiyonu testi negatif olan hastalarda önemli düzeyde tanısal düzeltici rol oynadı. Ayrıca, CURB-65 ve qSOFA skorları mortalite açısından önemli ölçüde farklılık gösterdi.

Anahtar Kelimeler: COVID-19, klinik özellikler, risk faktörleri, prognoz

\section{Introduction}

Coronavirus disease-2019 (COVID-19), which started in December 2019 in Wuhan, China, and was spread worldwide by severe acute respiratory syndrome-coronavirus-2 (SARSCoV-2), caused nearly 13 million confirmed cases and over 550 thousand deaths worldwide by July 2020 (1). More than 210 thousand people have been infected in Turkey, and more than 5300 deaths occurred (2).

Mortality rate was reported as $15 \%$ in the first periods. However, as the number of cases increased, this rate varied between $4.3 \%$ and $11 \%$. According to the latest data, mortality has decreased to $3.4 \%$. SARS-CoV-2 is more contagious than SARS-CoV and Middle East respiratory syndrome coronavirus (MERS-CoV), but the case fatality rate is lower (3). However, the SARS-CoV-2 case death rate is rapidly increasing. Besides, the actual mortality case-death rate is thought to be smaller than it was calculated only in (COVID-19) patients with symptoms severe enough to cause immediate evaluation and hospitalization (4).

Initial reports from affected patient populations in hospitals in China have shown that most patients with severe disease and poor prognosis are accompanied by comorbid conditions such as hypertension, diabetes, obesity, asthma, chronic obstructive pulmonary disease, or advanced age $(5,6)$.

This study was carried out in Kayseri City Hospital located in central Anatolia, a tertiary referral hospital with a total capacity of 1607 beds. The government previously determined the city hospital to provide healthcare for patients during COVID-19 pandemics. Our study aimed to examine demographic and clinical findings and prognosis of the patients during the first forty days of the pandemic.

\section{Material and Methods}

In this study, the cases diagnosed with COVID-19 were proven by the clinic and laboratory findings and they were followed-up and treated between March 13 and April 23, 2020, in Kayseri City Hospital, Training and Research Hospital with 1.607 bed capacity and 253 intensive care beds.

Approval was obtained from the Ethics Committee of Kayseri City Hospital for this study (approval no. 76397871/149, approval date: 09.07.2020).

Signed informed consent was exempted due to the retrospective nature of the study.

Inclusion criteria in the study: (1) Patients with a positive real-time reverse transcription-polymerase chain reaction (rRT-PCR) test using throat and nose swab samples with a pre-diagnosis of COVID-19, (2) rRT-PCR test negative during hospitalization, but thorax computed tomography (CT) imaging compatible with coronavirus pneumonia and patients with positive control rRT-PCR test.

Thorax CT classification; The North American Association of Radiology COVID-19 tomography findings are based on the ranking. This classification has a typical, indeterminate or atypical appearance and negative definitions of COVID-19 pneumonia (7).Accordingly, patients with a typical appearance on thorax CT were accepted as coronavirus pneumonia.

\section{Statistical Analysis}

In the statistical evaluation of the study's data, categorical data were evaluated as frequency and percentage. Continuous data were assessed as mean \pm standard deviation (SD) or median value (minimum-maximum) depending on the data's distribution. The Shapiro-Wilk test was used for normality controls of continuous measurements. After the normal distribution test of continuous variables, two independent group t-tests (independent-sample t-test) were used for the two-group comparisons. For variables that were not compatible with the normal distribution, the non-parametric Mann-Whitney $U$ test was used in two-group comparisons. Binary logistic regression analysis was used to identify independent risk factors for intensive care unit (ICU) and 
mortality admission. The significance level ( $p$-value) was taken as 0.05 .

\section{Results}

Between March 13, 2020, and April 23, 2020, a total of 1639 patients applied to the pandemic unit and emergency clinic pandemic unit of our hospital. One thousand two hundred thirty-one of the patients were hospitalized with the pre-diagnosis of COVID-19. In 235 of the hospitalized patients, the rRT-PCR test taken before hospitalization was positive; whereas 331 had the first rRT-PCR test negative (repeated rRT-PCR tests were positive during hospitalization). Still, there was a typical thorax CT image for COVID-19. A total of 561 patients with positive rRT-PCR test and thorax $\mathrm{CT}$ imaging were included in the study.

The patients' mean age was $53.5 \pm 20.3$ years, and the median age was 54 years inspections' and Internal Quality Reviews (IQRs: $38-70) .53 .7 \%(n=301)$ of the patients were male. 429 (76.5\%) of the patients were hospitalized in the ICU, while 132 (23.5\%) were hospitalized in the isolation wards. The average time between the onset of symptoms and admission to the hospital was 3.88 (SD: \pm 3.1 ) days. The median hospital stay of the patients was eight days (IQRs: 5-11).

The most common symptoms were fever, cough, shortness of breath, myalgia, weakness, headache, and nausea. The most common symptoms in patients were fever [257 (45.8\%)], cough [333 (59.4\%)], shortness of breath [220 (39.2\%)], weakness [148 (26.4\%)], and myalgia [130 (23.2\%)]. Less common symptoms were headache [7 (1.2\%)], nausea, and vomiting [13 (2.3\%)]. A total of 48 patients (8.6\%) did not have any symptoms at the time of presentation (Table 1 ).

While $21 \%$ of the patients $(n=118)$ had at least one comorbid disease, $21.7 \% \quad(n=122)$ had more than one additional disease. The most common comorbidities were hypertension (HT), 16.8\% ( $n=94$ ) diabetes mellitus (DM) and $15.3 \%(n=86)$ chronic obstructive pulmonary disease (COPD) with $20 \%(n=112)$. Of the patients included in the study, a total of $9.3 \%(n=52)$ deaths occurred. Initial clinical and laboratory characteristics of the patients are shown in Tables 1 and 2 .

In our study, antibiotics was administered in $86.5 \%$ of the patients, hydroxychloroquine in $30.8 \%$, oseltamivir in $44.9 \%$, and favipiravir in $10.7 \%$. Besides, convalescent plasma (CP) was applied to $1.8 \%$ of the patients and stem cell therapy to $3.2 \%$. No medical treatment was given to $7.7 \%$ of the patients (Table 1).

Compared patients admitted to the ICU with those admitted to isolation ward, patients admitted to the ICU were significantly older (69.7 \pm 14.6 years vs $48.5 \pm 19.1$ years). In addition, the patients who were admitted to ICU were more likely to have underlying comorbidities including HT (30.3\%

\begin{tabular}{|c|c|c|}
\hline Age, mean $( \pm$ SD) y & \multicolumn{2}{|c|}{$53.5 \pm(20.3)$} \\
\hline Gender & $\mathbf{n}$ & $(\%)$ \\
\hline Female & 260 & $(46.3)$ \\
\hline Male & 301 & $(53.7)$ \\
\hline Isolation ward & 429 & $(76.5)$ \\
\hline ICU & 132 & $(23.5)$ \\
\hline Died & 52 & $(9.3)$ \\
\hline Survive & 509 & $(90.7)$ \\
\hline $\begin{array}{l}\text { Onset of symptoms to hospital admission, } \\
\text { mean } \pm \text { SD (min-max) day }\end{array}$ & \multicolumn{2}{|c|}{$3.88 \pm 3.1(1-14)$} \\
\hline Length of stay in hospital. median IQRs. day & \multicolumn{2}{|c|}{8 (IQRs: 5- 11) } \\
\hline Initial signs and symptoms & $\mathbf{n}$ & $(\%)$ \\
\hline Fever & 257 & $(45.8)$ \\
\hline Cough & 333 & $(59.4)$ \\
\hline Dyspnea & 220 & $(39.3)$ \\
\hline Fatigue & 148 & $(26.4)$ \\
\hline Myalgia & 130 & $(23.2)$ \\
\hline Headache & 7 & $(1.2)$ \\
\hline Nausea & 13 & $(2.3)$ \\
\hline Asymptomatic & 48 & $(8.6)$ \\
\hline Initial laboratory findings & Median & IQRs \\
\hline White blood cell count. $\times 103 /$ uL & 7.27 & $(5.46-10)$ \\
\hline Neutrophil count ×103/uL & 4.8 & $(3.39-7.55)$ \\
\hline Lymphocyte count $\times 103 / u L$ & 1.55 & $(1.08-2.1)$ \\
\hline Blood urea nitrogen $\mathrm{mg} / \mathrm{dL}$ & 13 & $(10-20)$ \\
\hline Creatinine mg/dL & 0.83 & $(0.66-1.07)$ \\
\hline C-reactive protein $\mathrm{mg} / \mathrm{L}$ & 19.8 & $(5.1-63.9)$ \\
\hline Procalcitonin $\mu \mathrm{g} / \mathrm{L}$ & 0.08 & $(0.05-0.17)$ \\
\hline Lactate dehydrogenase U/L & 244 & $(194-327)$ \\
\hline Gamma glutamyltransferase U/L & 24 & $(16-42)$ \\
\hline D-dimer mg/L & 540 & $(280-1.207)$ \\
\hline \multirow[t]{2}{*}{ Creatine kinase U/L } & 77 & $(134.5)$ \\
\hline & Mean & \pm SD \\
\hline Albumin $\mathrm{g} / \mathrm{L}$ & 39.6 & 5.9 \\
\hline Platelet count $\times 103 / u L$ & 233.3 & 75.1 \\
\hline Treatment & $\mathbf{n}$ & $(\%)$ \\
\hline Antiviral therapy & - & - \\
\hline Hydroxychloroquine & 173 & $(30.8)$ \\
\hline Favipiravir & 60 & $(10.7)$ \\
\hline Oseltamivir & 252 & $(44.9)$ \\
\hline Lopinavir-ritonavir & 4 & $(0.7)$ \\
\hline Antibiotic treatment & 485 & $(86.5)$ \\
\hline Plasma & 10 & $(1.8)$ \\
\hline Stem cell therapy & 18 & $(3.2)$ \\
\hline Without any treatment & 43 & $(7.7)$ \\
\hline
\end{tabular}


vs $16.8 \%)$, DM ( $26.5 \%$ vs $13.8 \%)$, COPD (22.7\% vs $13.1 \%)$, cardiovascular disease (CVD) (23.5\% vs $10.5 \%)$, chronic kidney disease (CKD) (4.5\% vs $1.2 \%)$, and cancer ( $9.8 \%$ vs $0.9 \%)$. ( $p$ values $=<0.005)$.

Over the age of sixty-five years, coronary artery disease, malignancy, lymphopenia, and elevation of some laboratory values were determined as significant risk factors related to ICU hospitalization and mortality (Table 3).

There was a statistically significant difference in ICU and mortality between the CURB-65 score, thorax CT groups (typical, indeterminate, atypical, and negative), and diagnosed unit (emergency room vs pandemic) groups. There was no statistically significant difference in ICU and mortality between the onset of symptoms and hospital admission. While there was no statistically significant difference between the qSOFA criteria groups in terms of ICU, there was a statistically significant difference in terms of mortality (Table 2,4).

There were statistically significant differences in the number of laboratory values such as white blood cell and neutrophil count and D-dimer, procalcitonin, BUN, and creatinine levels in ICU hospitalization and mortality (Table $2,4)$.

\section{Discussion}

Our study covered 40 days after the first COVID-19 case in our region on March 13,2020. As shown in Figure 1, there was an increasing trend of hospitalized patients over time. During this first 40 days, it was observed that hospitalization reached its maximum on April 6, 2020. This finding may confirm the rapid spread of the disease in the population. Several studies have reported that the transmission rate (R0) of SARS-CoV-2 infection is between 0.3 and 3.77. This difference can be thought to be due to different sample sizes and possible viral variation (8). Also, super emitters have been reported during SARS and MERS outbreaks. It has been emphasized that focusing on asymptomatic transmitters is required, especially in preventing SARS-CoV- 2 spread $(8,9)$. In our study, the rate of the asymptomatic patient group was $8.6 \%$.

Studies conducted in China when the disease was first detected showed that most patients with severe disease and poor prognosis were accompanied by comorbid conditions such as HT, DM, obesity, asthma, COPD, or advanced age $(5,6)$. The majority of 52 deaths in our study were 70 years old and older ( $n=35$ ), and $34.6 \%$ of the patients died with at least one comorbidity such as DM, HT, and COPD.

Mortality rates were reported as $15 \%$ in the first periods, but as the number of cases increased, the case fatality rates ranged from $4.3 \%$ to $11 \%$. According to the latest data, it has decreased to $3.4 \%$ (4). In our study, the case fatality rate was determined as $4.2 \%$.
Older age is a significant risk factor for the death or ICU need of patients with COVID-19 $(10,11,12)$. Also, advanced age and increased comorbidity are independent predictors for COVID-19 patients in in-hospital mortality (13). In our study, common risk factors for ICU care and death were advanced age, coronary artery disease, and malignancy.

Low lymphocyte levels in the disease's diagnosis and throughout the disease were associated with mortality. Also, high D-dimer, troponin I, and LDH values were defined as poor prognostic factors associated with death and severe illness $(7,11)$. In our study, significant risk factors were; 1 . leukocyte count above ten thousand, 2 . the presence of lymphopenia, 3. high levels of urea and creatinine, CRP, procalcitonin, LDH, d-dimer, and cTnl.

The standard diagnostic method for COVID-19 is the rRT-PCR test with high specificity but low sensitivity. It has been shown that nasopharyngeal swab has a sensitivity of approximately $60 \%$, tracheal aspirates roughly $70 \%$, and bronchoalveolar lavage in the range of $90 \%$ to $95 \%$ to detect SARS-CoV-2 $(14,15)$. The performance of tests that detect viral RNA depends on the viral RNA present in the sample taken. In practice, negative test results obtained especially with nasopharyngeal and oropharyngeal swabs do not rule out the possibility of COVID-19 infection. This may be due to insufficient viral RNA in the sample due to the low quality of the sample obtained with false-negative PCR results, the collection time of the clinical sample, and the sample's transfer under unacceptable conditions (16).

Another problem is that the rRT-PCR test result takes about two days. Besides, in cases where the rRT-PCR test is challenging to provide, some clinicians may refer to the patient's thoracic $\mathrm{CT}$ for the decision because thorax $\mathrm{CT}$ can correct the false negativity of rRT-PCR test in the early stage of the disease. However, it should be kept in mind that CT findings may also be normal within the first 2-4 days when symptoms develop (17). In a study, radiologists showed that thoracic CT had high specificity but moderate sensitivity in distinguishing COVID-19 from viral pneumonia (18). In another study, while the initial rRT-PCR sensitivity was only $83 \%$, it was shown that the CT sensitivity was $97 \%$ (19). In our research, while the first rRT-PCR test was negative in $59 \%$ of the cases, thorax CT was positive, and repeated rRT-PCR tests were positive in their follow-up. The high sensitivity of thoracic CT can explain this situation in the early period and the inexperience had during the first 40 days of taking and testing nasopharyngeal swabs in our study patients. However, in $11 \%$ of the patients, while the first rRT-PCR test was positive, thorax $\mathrm{CT}$ was negative/normal.

The consisting of confusion, urea level, respiratory rate, blood pressure, and age $>65$ years (CURB-65) score, which is used to determine the need for hospitalization in adults 
Table 2. Basic characteristics of patients with COVID-19

\begin{tabular}{|c|c|c|c|c|}
\hline & \multicolumn{4}{|l|}{ no (\%) } \\
\hline & Total & ICU & non-ICU & $p$ \\
\hline \multicolumn{5}{|l|}{ Age, range y } \\
\hline $40-49$ & 78 (13.9) & $4(3)$ & $74(17.2)$ & \multirow{3}{*}{$<0.001$} \\
\hline $50-59$ & $96(17.1)$ & $19(14.4)$ & 77 (17.9) & \\
\hline $60-69$ & $87(15.5)$ & $35(26.5)$ & $52(12.1)$ & \\
\hline \multicolumn{5}{|l|}{ Gender } \\
\hline Female & $260(46.3)$ & $60(45.5)$ & $200(46.6)$ & \multirow{2}{*}{0.814} \\
\hline Male & $301(53.7)$ & $72(54.5)$ & $229(53.4)$ & \\
\hline \multicolumn{5}{|l|}{ Comorbidities } \\
\hline Hypertension & $112(20)$ & $40(30.3)$ & $72(16.8)$ & 0.001 \\
\hline Diabetes & $94(16.8)$ & $35(26.5)$ & $59(13.8)$ & 0.001 \\
\hline \multicolumn{5}{|l|}{ Number of comorbidities } \\
\hline 0 & $321(57.2)$ & $39(29.5)$ & $282(65.7)$ & \multirow{3}{*}{$<0.001$} \\
\hline 1 & $118(21)$ & $44(33.3)$ & $74(17.2)$ & \\
\hline 2 or more & $122(21.7)$ & 49 (37.1) & $73(17)$ & \\
\hline \multicolumn{5}{|l|}{ CT findings } \\
\hline Negative/normal & $63(11.2)$ & $4(3)$ & $59(13.8)$ & \multirow{4}{*}{0.001} \\
\hline Typical & $428(76.3)$ & $104(78.8)$ & $324(75.5)$ & \\
\hline Indeterminate & $49(8.7)$ & $18(13.6)$ & $31(7.2)$ & \\
\hline Atypical & $21(3.7)$ & $6(4.5)$ & $15(3.5)$ & \\
\hline \multicolumn{5}{|l|}{ qSOFA criteria } \\
\hline$<2$ & $237(42.2)$ & 57 (43.2) & $180(42)$ & 0.803 \\
\hline Pandemic clinic & 307 (54.7) & $38(23.5)$ & $269(76.5)$ & $<0.001$ \\
\hline \multirow[t]{2}{*}{ Onset of symptom to hospital admission mean $( \pm$ SD) } & $3.88 \pm 3.1$ & $3.55 \pm 3.01$ & $3.98 \pm 3.1$ & 0.171 \\
\hline & \multicolumn{4}{|l|}{ Median (IQR) } \\
\hline White blood cell count $\times 10^{3} / \mathrm{uL}$ & $7.27(5.46-10)$ & $9.3(6.7-14.2)$ & $6.9(5.3-9.2)$ & $<0.001$ \\
\hline Neutrophil count $\times 10^{3} / \mathrm{uL}$ & $4.8(3.39-7.55)$ & $7.2(4.5-11.3)$ & $4.2(3-6.3)$ & $<0.001$ \\
\hline Lymphocyte count $\times 10^{3} / \mathrm{uL}$ & $1.55(1.08-2.1)$ & $1.09(0.76-1.7)$ & $1.66(1.2-2.2)$ & $<0.001$ \\
\hline Blood urea nitrogen $\mathrm{mg} / \mathrm{dL}$ & $13(10-20)$ & $20(14-35.5)$ & $12(9-17)$ & $<0.001$ \\
\hline Creatinine $\mathrm{mg} / \mathrm{dL}$ & $0.83(0.66-1.07)$ & $1.04(0.76-1.58)$ & $0.8(0.65-0.96)$ & $<0.001$ \\
\hline C-reactive protein $\mathrm{mg} / \mathrm{L}$ & $19.8(5.1-63.9)$ & $62.5(33.6-117)$ & $11.6(3.7-40.9)$ & $<0.001$ \\
\hline Procalcitonin $\mu \mathrm{g} / \mathrm{L}$ & $0.08(0.05-0.17)$ & $0.20(0.09-0.65)$ & $0.06(0.04-0.10)$ & $<0.001$ \\
\hline Lactate dehydrogenase U/L & $244(194-327)$ & $297(228-404)$ & $229(188-292)$ & $<0.001$ \\
\hline Gamma Glutamyltransferase U/L & $24(16-42)$ & $27(18-51)$ & $21(15-40.5)$ & 0.017 \\
\hline D-dimer mg/L & $540(280-1.207)$ & $1.250(672-3.322)$ & $410(250-805)$ & $<0.001$ \\
\hline \multirow[t]{2}{*}{ Creatine kinase U/L } & 77 (134.5) & $83(59-159)$ & $72(51-117)$ & 0.134 \\
\hline & \multicolumn{4}{|l|}{ Mean \pm SD } \\
\hline Albumin $\mathrm{g} / \mathrm{L}$ & $39.6 \pm 5.9$ & $34.9 \pm 5.7$ & $41.3 \pm 5.05$ & $<0.001$ \\
\hline Platelet count $\times 10^{3} / \mathrm{uL}$ & $233.3 \pm 75.1$ & $222.5 \pm 80.7$ & $236 \pm 73$ & 0.058 \\
\hline
\end{tabular}


Table 3. Risk factors for ICU care and mortality in COVID-19 patients

\begin{tabular}{|c|c|c|c|c|}
\hline & \multicolumn{2}{|l|}{ ICU } & \multicolumn{2}{|l|}{ Mortality } \\
\hline & OR (95\% CI) & p & OR (95\% Cl) & p \\
\hline Age years & $0.934(0.921-0.948)$ & $<0.001$ & $1.08(1.06-1.11)$ & $<0.001$ \\
\hline Female vs male & - & 0.814 & - & 0.579 \\
\hline \multicolumn{5}{|l|}{ Comorbidities } \\
\hline Hypertension & $1.7(1-2.7)$ & 0.035 & - & 0.825 \\
\hline COPD & - & 0.161 & - & 0.303 \\
\hline CVD & $1.9(1.1-3.4)$ & 0.014 & $2.9(1.4-6)$ & 0.004 \\
\hline CKD & - & 0.133 & - & 0.241 \\
\hline Malignancy & $9.2(2.8-29.6)$ & $<0.001$ & $19.6(6.6-58)$ & $<0.001$ \\
\hline \multicolumn{5}{|l|}{ Laboratory findings } \\
\hline$>10$ & $5.3(2-13.8)$ & $<0.001$ & $11.3(1.5-86.1)$ & 0.019 \\
\hline \multicolumn{5}{|l|}{ Lymphocyte count } \\
\hline$\geqslant 1.1$ (ref) & - & - & - & - \\
\hline$<1.1$ & $4.9(3.1-7.6)$ & $<0.001$ & $3.8(2.1-6.9)$ & $<0.001$ \\
\hline \multicolumn{5}{|l|}{ Bun } \\
\hline$\leqslant 19$ (ref) & - & - & - & - \\
\hline$>19$ & $5.2(3.2-8.5)$ & $<0.001$ & $11.1(5.4-22.6)$ & $<0.001$ \\
\hline \multicolumn{5}{|l|}{ Creatinine } \\
\hline$\leqslant 1.2$ (ref) & - & - & - & - \\
\hline$>1.2$ & $4.2(2.7-6.7)$ & $<0.001$ & $6(3.3-10.9)$ & $<0.001$ \\
\hline$\leqslant 245$ (ref) & - & - & - & - \\
\hline$>245$ & $2.7(1.6-4.3)$ & $<0.001$ & $3.2(1.6-6.4)$ & 0.001 \\
\hline \multicolumn{5}{|l|}{ D-dimer } \\
\hline$\leqslant 500$ (ref) & - & - & - & - \\
\hline$>500$ & $6(3.2-11.4)$ & $<0.001$ & $10(3-33.8)$ & $<0.001$ \\
\hline \multicolumn{5}{|l|}{ Creatine kinase } \\
\hline$\leqslant 185$ (ref) & - & - & - & - \\
\hline$>185$ & $3.4(1.3-8.7)$ & 0.010 & - & 0.66 \\
\hline \multicolumn{5}{|l|}{ Fibrinogen } \\
\hline Normal (ref) & - & - & - & - \\
\hline High & $3.4(1.7-6.5)$ & $<0.001$ & - & 0.308 \\
\hline \multicolumn{5}{|l|}{ cTnl (Troponin I) } \\
\hline$<0.3$ (ref) & - & - & & \\
\hline$\geqslant 3.3$ & $8.9(2.8-28.2)$ & $<0.001$ & $9.18(3.3-25.5)$ & $<0.001$ \\
\hline
\end{tabular}


Table 4. Basic characteristics of patients with COVID-19

\begin{tabular}{|c|c|c|c|c|}
\hline & Total & Death & Survive & $p$ \\
\hline Age mean $( \pm$ SD) y & $53.5 \pm 20.3$ & $74.9 \pm 13.8$ & $51.3 \pm 19.5$ & $<0.001$ \\
\hline \multicolumn{5}{|l|}{ Age range y } \\
\hline$<39$ & $157(28)$ & $1(1.9)$ & $156(30.6)$ & \multirow{5}{*}{$<0.001$} \\
\hline $40-49$ & $78(13.9)$ & $1(1.9)$ & $77(15.1)$ & \\
\hline $50-59$ & $96(17.1)$ & $3(5.8)$ & $93(18.3)$ & \\
\hline $60-69$ & 87 (15.5) & $12(23.1)$ & 75 (14.7) & \\
\hline$\geqslant 70$ & $143(25.5)$ & $35(67.3)$ & $108(21.2)$ & \\
\hline \multicolumn{5}{|l|}{ Gender } \\
\hline Female & $260(46.3)$ & $26(50)$ & $234(46)$ & \multirow{2}{*}{0.579} \\
\hline Male & $301(53.7)$ & $26(50)$ & $275(54)$ & \\
\hline \multicolumn{5}{|l|}{ Comorbidities } \\
\hline Hypertension & $112(20)$ & $12(23.1)$ & $100(19.6)$ & 0.556 \\
\hline Diabetes & $94(16.8)$ & $11(21.2)$ & $83(16.3)$ & 0.373 \\
\hline COPD & $86(15.3)$ & $13(25)$ & $73(14.3)$ & 0.042 \\
\hline Cardiovascular disease & $76(13.5)$ & $16(30.8)$ & $60(11.8)$ & $<0.001$ \\
\hline Chronic kidney disease & $11(2)$ & $3(5.8)$ & $8(1.6)$ & 0.038 \\
\hline Malignancy & $17(3)$ & $11(21.2)$ & $6(1.2)$ & $<0.001$ \\
\hline \multicolumn{5}{|l|}{ Number of comorbidities } \\
\hline 0 & $321(57.2)$ & $12(23.1)$ & $309(60.7)$ & \multirow{3}{*}{$<0.001$} \\
\hline 1 & $118(21)$ & $18(34.6)$ & $100(19.6)$ & \\
\hline 2 or more & $122(21.7)$ & $22(42.3)$ & $100(19.6)$ & \\
\hline \multicolumn{5}{|l|}{ CT findings } \\
\hline Negative/normal & $63(11.2)$ & $2(3.8)$ & $61(12)$ & \multirow{4}{*}{$<0.001$} \\
\hline Typical & $428(76.3)$ & $30(57.7)$ & $398(78.2)$ & \\
\hline Indeterminate & $49(8.7)$ & $13(25)$ & $36(7.1)$ & \\
\hline Atypical & $21(3.7)$ & 7 (13.5) & $14(2.8)$ & \\
\hline \multicolumn{5}{|l|}{ qSOFA criteria } \\
\hline$<2$ & $237(42.2)$ & $10(19.2)$ & $227(44.6)$ & \multirow{2}{*}{$<0.001$} \\
\hline$\geqslant 2$ & $324(57.8)$ & $42(80.8)$ & $282(55.4)$ & \\
\hline \multicolumn{5}{|l|}{ CURB-65 score } \\
\hline 0 or 1 & $15(2.7)$ & $0(0)$ & $15(2.9)$ & \multirow{3}{*}{$<0.001$} \\
\hline 2 & $498(88.8)$ & $36(69.2)$ & $462(90.8)$ & \\
\hline$\geqslant 3$ & $48(8.6)$ & $16(30.8)$ & $32(6.3)$ & \\
\hline \multicolumn{5}{|l|}{ Diagnosis unit } \\
\hline Emergency service & $254(45.3)$ & $40(76.9)$ & $214(42)$ & \multirow{2}{*}{$<0.001$} \\
\hline Pandemic clinic & 307 (54.7) & $12(23.1)$ & $295(58)$ & \\
\hline \multirow[t]{3}{*}{ Onset of symptom to hospital admission mean $( \pm$ SD) } & $3.88 \pm 3.1$ & $2.92 \pm 2.8$ & $3.97 \pm 3.1$ & 0.020 \\
\hline & \multicolumn{4}{|l|}{ Median (IQR) } \\
\hline & Total & Death & Survive & $\mathbf{p}$ \\
\hline White blood cell count $\times 10^{3} / \mathrm{uL}$ & $7.27(5.46-10)$ & $11.8(7.9-16.5)$ & $7.1(5.3-9.5)$ & $<0.001$ \\
\hline Neutrophil count $\times 10^{3} / \mathrm{uL}$ & $4.8(3.39-7.55)$ & $9.7(6.3-14)$ & $4.5(3.2-6.9)$ & $<0.001$ \\
\hline Lymphocyte count $\times 10^{3} / \mathrm{uL}$ & $1.55(1.08-2.1)$ & $1.06(0.76-1.58)$ & $1.6(1.1-2.1)$ & $<0.001$ \\
\hline Blood urea nitrogen $\mathrm{mg} / \mathrm{dL}$ & $13(10-20)$ & $31.5(18.2-54)$ & $13(10-17)$ & $<0.001$ \\
\hline Creatinine mg/dL & $0.83(0.66-1.07)$ & $1.2(0.9-2.2)$ & $0.8(0.65-1.0)$ & $<0.001$ \\
\hline C-reactive protein $\mathrm{mg} / \mathrm{L}$ & $19.8(5.1-63.9)$ & $67.3(29.3-188)$ & $16(4.8-55.9)$ & $<0.001$ \\
\hline Procalcitonin $\mu \mathrm{g} / \mathrm{L}$ & $0.08(0.05-0.17)$ & $0.26(0.11-0.77)$ & $0.07(0.04-0.13)$ & $<0.001$ \\
\hline Lactate dehydrogenase U/L & $244(194-327)$ & $345(231-435)$ & $238(190-313)$ & $<0.001$ \\
\hline Gamma glutamyltransferase U/L & $24(16-42)$ & $27(16-60)$ & $22(15-41)$ & 0.123 \\
\hline D-dimer mg/L & $540(280-1.207)$ & $1910(1.080-5.820)$ & $490(260-1.010)$ & $<0.001$ \\
\hline \multirow[t]{2}{*}{ Creatine kinase U/L } & $77(134.5)$ & $136(61-217)$ & $74(51-118)$ & 0.046 \\
\hline & Mean \pm SD & & & \\
\hline Albumin g/L & $39.6 \pm 5.9$ & $33.1 \pm 6.7$ & $40.5 \pm 5.2$ & 0.029 \\
\hline Platelet count $\times 10^{3} / \mathrm{uL}$ & $233.3 \pm 75.1$ & $244 \pm 91.8$ & $232 \pm 73.1$ & 0.086 \\
\hline
\end{tabular}




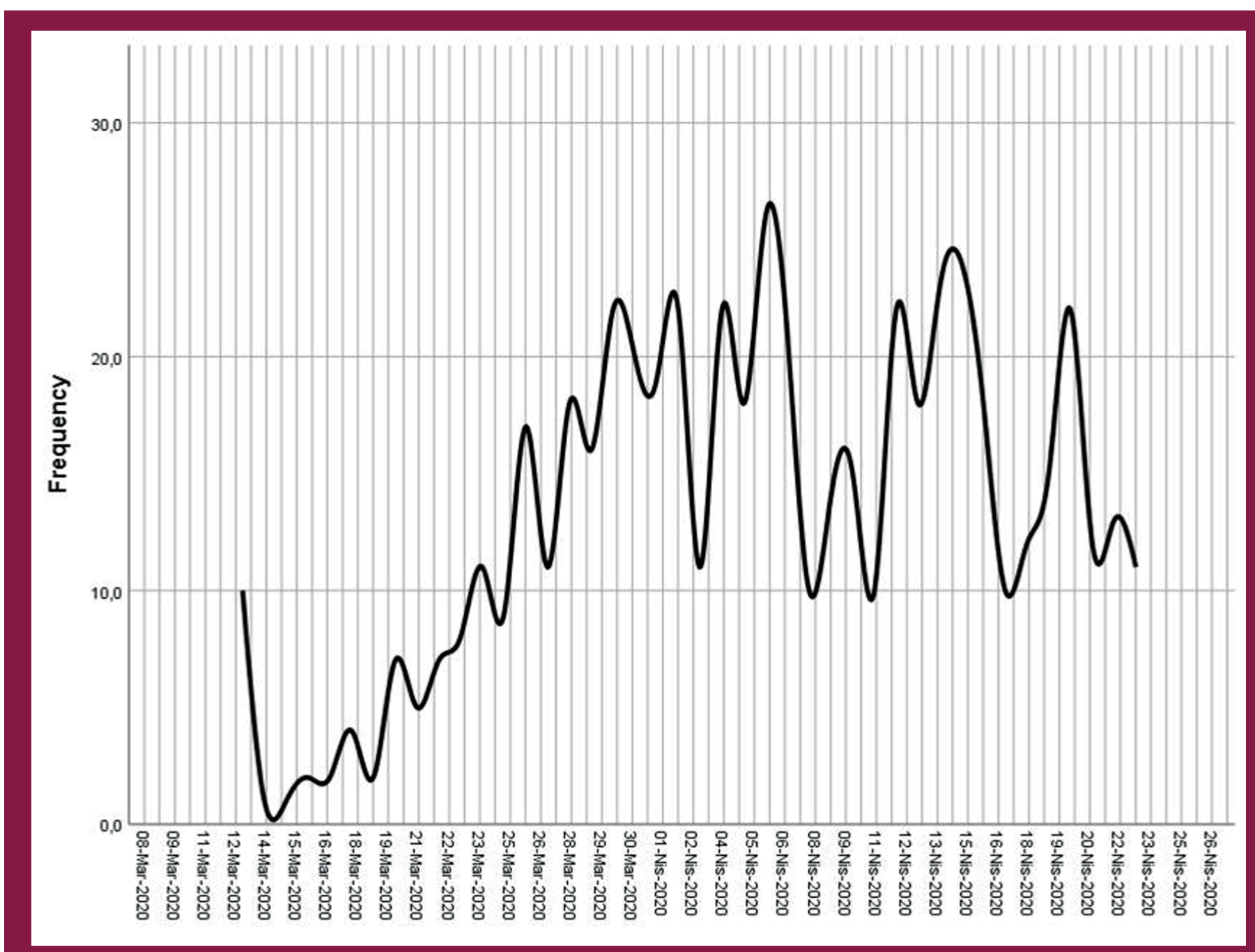

Figure. 1. The distribution of patients according to the dates of hospital admission $(n=561)$

diagnosed with community-acquired pneumonia, has a low level of evidence (20). Also, the CURB-65 score ranges from 0 to 5 . zero-one point shows a low risk for mortality, while 2 points or higher are associated with higher mortality. In a study of 681 COVID-19 patients, it was demonstrated that the CURB-65 score was $\geqslant 2$, it had a useful, distinctive ability in predicting 30-day mortality, and its sensitivity was $73 \%$, and its specificity was $85 \%$ (21). In our study, the CURB-65 score had a significant difference between ICU care and mortality groups.

qSOFA criterion can be used to determine sepsis-induced prognosis in adult patients with suspicious infection in non-hospital, emergency, or general hospital conditions. qSOFA criteria positivity is defined as having at least 2 of the respiratory rate 22 or more minutes, mental state change, or systolic blood pressure $100 \mathrm{mmHg}$ or below (22). A study conducted in 110 hospitalized COVID-19 patients stated that the criteria for systemic inflammatory response syndrome and qSOFA were low in predicting clinical prognosis, and this may be because there are many "silent hypoxemia" patients in COVID-19. Silent hypoxemia describes patients who breathe easily but have low oxygen saturation in pulse oximetry (23). In our study, while there were no differences between ICU care groups in terms of the qSOFA criteria, there were differences between mortality groups.

While the main reason for the rate of increase in COVID-19 cases is the person-to-person transmission, the main reason for the rise in mortality is the lack of a proven medical treatment specific to COVID-19. Medical therapies currently in use are therapies applied to prevent the virus's entry into the cell, inhibit or reduce its replication, and suppress the increased inflammation response. Besides, CP treatment, which includes antibodies of infected and recovered patients, is among the options (24). The uncertainty of treatment during 
pandemic and the lack of information on viral pathogenesis challenged the procedure applied in our study.

Hydroxychloroquine and oseltamivir inhibit the entry of the virus into the cell. However, with the recent studies, the evidence showing hydroxychloroquine's in vitro activity against SARS-CoV-2 is limited (25). Oseltamivir is a neuraminidase inhibitor used in influenza treatment. Concurrent influenza infection was detected in approximately $4.3 \%$ of COVID-19 patients. However, the place of oseltamivir in the treatment of COVID-19 is controversial (26). Due to the high frequency of influenza infection between March and April, our study rate of using oseltamivir was high when our study was conducted.

Due to the limitations experienced in the first period in our region, we could not apply the necessary amounts of favipiravir and remdesivir treatments among treatments that inhibit or reduce the virus's replication. The same reason was valid for the procedures applied to suppress the increased inflammation response.

The World Health Organization and the American Food and Drug Administration stated that the use of $\mathrm{CP}$ containing anti-SARS COV-2 antibody could be effective against infection. A guideline has been prepared for the preparation and clinical use of $C P$ in our country. CP usage criteria include the presence of pneumonia with diffuse bilateral involvement in thorax $\mathrm{CT}$, the need for mechanical ventilation, and having poor prognostic parameters (27). CP was applied to ten patients in our study. Mesenchymal stem cells contain multipotent stromal cells that support immunomodulation and regeneration. Stem cells show antiviral activity by suppressing viral replication, viral transmission and viral lung epithelial cell damage. And stem cell therapy is safe and could benefit COVID-19 patients with hypoxic respiratory failure and ARDS $(28,29)$. In our study, stem cell therapy was applied to eighteen patients.

\section{Study Limitations}

Our study's significant limitations include its being retrospective, having short working time, and being performed only on hospitalized patients. Secondly, this study was conducted in a single-center tertiary hospital with limited sample size. Therefore, this study is likely to include patients with a disproportionately poor prognosis.

Also, since our study included the 40 days after the first COVID-19 case detected in our region, there were limitations related to patient management, deficiencies in the acquisition or evaluation of rRT-PCR tests and the treatment algorithm.

\section{Conclusions}

In our study, the essential risk factors related to critical care and mortality were: 1 . Advanced age, 2 . Having coronary artery disease and malignancy, 3 . Leukocyte count over ten thousand, 4. Presence of lymphopenia, 5. Elevation of urea and creatinine, CRP, procalcitonin, LDH, d-dimer and CTnI. In our study, thorax CT played a vital corrective role in patients whose first rRT-PCR test was negative. As well, the CURB-65 and qSOFA scores were substantially different in terms of mortality.

\section{Highlight Key Points}

While the COVID-19 pandemic is still ongoing, our study covers the first 40 days. During this period, both the increase in knowledge about the disease and the patient approach change shown undeniable differences.

Our first focus was to retrospectively address the early stages of the long pandemic process and examine the diagnostic difficulties, patient follow-up, treatment approaches and results of the first period.

Another critical point was the flaws in the diagnostic process. Due to different reasons, lower rRT-PCR sensitivity than thoracic CT sensitivity causes diagnostic delays and errors.

Finally, low lymphocyte levels were associated with mortality in the diagnosis. Throughout the disease, high D-dimer, troponin I and LDH values were defined as poor prognostic factors associated with death and severe illness.

\section{Ethics}

Ethics Committee Approval: Approval was obtained from the Ethics Committee of Kayseri City Hospital for this study. (approval no. 76397871/149, approval date: 09.07.2020)

Informed Consent: Signed informed consent was exempted due to the retrospective nature of the study.

Peer-review: Internally peer-reviewed.

\section{Authorship Contributions}

Surgical and Medical Practices: A.K.T., Concept: A.K.T., Design:A.K.T., Data Collection or Processing:A.K.T., E.E.,Z.B.D., I.T., E.S., I.Ç., Analysis or Interpretation: A.K.T., A.U.K., I.T., I..Ç., Literature Search: E.E., Z.B.D., Writing: A.K.T., A.U.K., I.T., I.Ç.

Conflict of Interest: No conflict of interest was declared by the authors.

Financial Disclosure: The authors declared that this study received no financial support.

\section{References}

1. World Health Organization [Internet]. Coronavirus disease 2019 (COVID-19): Situation Report Last Accessed Date: 16.05.2020. Available from: https://reliefweb.int/report/world/coronavirus-disease-2019-covid19-situation-report-116-15-may-2020. [Crossref]

2. T.C Sağlık Bakanlığı [Internet]. Genel Koronavirüs Tablosu Last Accessed Date: 16.05.2020. Available from: https://covid19.saglik.gov.tr/ [Crossref]

3. Rajgor DD, Lee MH, Archuleta S, Bagdasarian N, Quek SC. The many 
estimates of the COVID-19 case fatality rate. Lancet Infect Dis. 2020;20:776-777. [Crossref]

4. Giwa AL, Desai A, Duca A. Novel 2019 coronavirus SARS-CoV-2 (COVID-19): An updated overview for emergency clinicians. Emerg Med Pract. 2020;22:1-28. [Crossref]

5. Wang D, Hu B, Hu C, Zhu F, Liu X, Zhang J, et al. Clinical characteristics of 138 hospitalized patients with 2019 novel coronavirus-Infected pneumonia in Wuhan, China. JAMA. 2020 17;323:1061-1069. [Crossref]

6. Chen N, Zhou M, Dong X, Qu J, Gong F, Han Y, et al. Epidemiological and clinical characteristics of 99 cases of 2019 novel coronavirus pneumonia in Wuhan, China: a descriptive study. Lancet. 2020;395:507-513. [Crossref]

7. Simpson S, Kay FU, Abbara S, Bhalla S, Chung JH, Chung M, et al. Radiological Society of North America Expert Consensus Statement on Reporting Chest CT Findings Related to COVID-19. Endorsed by the Society of Thoracic Radiology, the American College of Radiology, and RSNA Radiol Cardiothorac Imaging. 2020 2:2. [Crossref]

8. Sun P, Lu X, Xu C, Sun W, Pan B. Understanding of COVID-19 based on current evidence.J Med Virol. 2020;92:548-551. [Crossref]

9. Wong G, Liu W, Liu Y, Zhou B, Bi Y, Gao GF. MERS, SARS, and Ebola: The Role of Super-Spreaders in Infectious Disease. Cell Host Microbe. 2015;18:398401. [Crossref]

10. Richardson S, Hirsch JS, Narasimhan M, Crawford JM, McGinn T, Davidson $\mathrm{KW}$, et al. Presenting characteristics, comorbidities, and outcomes among 5700 patients hospitalized with COVID-19 in the New York City area. JAMA. 2020;323:2052-2059. [Crossref]

11. Zhou F, Yu T, Du R, Fan G, Liu Y, Liu Z, et al. Clinical course and risk factors for mortality of adult inpatients with COVID-19 in Wuhan, China: a retrospective cohort study. Lancet. 2020 28;395:1054-1062. [Crossref]

12. Wu C, Chen X, Cai Y, Xia J, Zhou X, Xu S, et al. Risk factors associated with acute respiratory distress syndrome and death in patients with coronavirus disease 2019 pneumonia in Wuhan, China. JAMA Intern Med. 2020;180:934-943. [Crossref]

13. Imam Z, Odish F, Gill I, O'Connor D, Armstrong J, Vanood A, et al. Older age and comorbidity are independent mortality predictors in a large cohort of 1305 COVID-19 patients in Michigan, United States. J Intern Med. 2020;288:469-476. [Crossref]

14. Yang Y, Yang M, Shen C, Wang F, Yuan J, Li J, et al. Evaluating the accuracy of different respiratory specimens in the laboratory diagnosis and monitoring the viral shedding of 2019-nCoV infections. medRxiv 2020.02.11.20021493 doi: 10.1101/2020.02.11.20021493. [Crossref]

15. Wang W, Xu Y, Gao R, Lu R, Han K, Wu G, et al. Detection of SARS-CoV-2 in Different Types of Clinical Specimens. JAMA. 2020;323:1843-1844. [Crossref]
16. Winichakoon P, Chaiwarith R, Liwsrisakun C, Salee P, Goonna A, Limsukon $A$, et al. Negative nasopharyngeal and oropharyngeal swabs do not rule out COVID-19. J Clin Microbiol. 2020;58:e00297-e00220. doi: 10.1128/ JCM.00297-00220.

17. Gezer NS. How to deal with COVID-19 pandemic: A radiologic approach. Turk Thorac J. 2020;21:219-220. [Crossref]

18. Bai HX, Hsieh B, Xiong Z, Halsey K, Choi JW, Tran TML, et al. Performance of radiologists in differentiating COVID-19 from non-COVID-19 viral pneumonia at chest CT. Radiology. 2020;296:E46-E54. doi: 10.1148/ radiol.2020200823.

19. Long C, Xu H, Shen Q, Zhang X, Fan B, Wang C, et al. Diagnosis of the coronavirus disease (COVID-19): rRT-PCR or CT? Eur J Radiol. 2020;126:108961. doi: 10.1016/j.ejrad.2020.108961.

20. Metlay JP, Waterer GW, Long AC, Anzueto A, Brozek J, Crothers K, et al. Diagnosis and treatment of adults with community-acquired pneumonia. an official clinical practice Guideline of the American Thoracic Society and Infectious Diseases Society of America. Am J Respir Crit Care Med. 2019;200:e45-e67. doi: 10.1164/rccm.201908-1581ST.

21. Satici C, Demirkol MA, Sargin Altunok E, Gursoy B, Alkan M, Kamat S, et al. Performance of pneumonia severity index and CURB-65 in predicting 30day mortality in patients with COVID-19. Int J Infect Dis. 2020;98:84-89. [Crossref]

22. Singer M, Deutschman CS, Seymour CW, Shankar-Hari M, Annane D, Bauer $M$, et al. The third International consensus definitions for sepsis and septic shock (sepsis-3). JAMA. 2016;315:801-810.

23. Jang JG, Hur J, Hong KS, Lee W, Ahn JH. Prognostic accuracy of the SIRS, qSOFA, and NEWS for early detection of clinical deterioration in SARSCoV-2 infected patients. J Korean Med Sci. 2020;35:e234. doi: 10.3346/ jkms.2020.35.e234.

24. Gbinigie K, Frie K. Should chloroquine and hydroxychloroquine be used to treat COVID-19? A rapid review. BJGP Open. 2020;4:bjgpopen20X101069. doi: 10.3399/bjgpopen20X101069.

25. Muralidharan N, Sakthivel R, Velmurugan D, Gromiha MM. Computational studies of drug repurposing and synergism of lopinavir, oseltamivir and ritonavir binding with SARS-CoV-2 protease against COVID-19.J Biomol Struct Dyn. 2020;1-6. [Crossref]

26. Atalay S, Ersan G. Treatment of COVID-19. J Tepecik Educ Res Hosp. 2020;30:126-134. [Crossref]

27. Eren E, Kiliç AU. Current treatment optıons for covid - 19. Science \& Healthcare. 2020;3:5-11. for details: https://newjournal.ssmu.kz/upload/ iblock/af8/5_11_-3_22_2020.pdf [Crossref]

28. Durand N, Mallea J,Zubair AC. Insights into the use of mesenchymal stem cells in COVID-19 mediated acute respiratory failure. Npj Regen Med. 2020;5:1-9. [Crossref] 